\title{
Synergia w architekturze kurortu nadmorskiego - studium przypadku Sopot
}

\author{
Krystyna Pokrzywnicka
}

\author{
Katedra Architektury Stużby Zdrowia, Wydział Architektury, Politechnika Gdańska, \\ e-mail:krystyna_pokrzywnicka@op.pl
}

Streszczenie: Sopot - znany nadbałtycki kurort stanowi znakomite pole badań nowych tendencji kreacji przestrzeni miejskiej w obszarze architektury mieszkaniowej, (pensjonatowej) obiektów ochrony zdrowia oraz rekreacyjno-sportowej, także, co bardzo ważne - relacji miasta i pasma przyplażowego, intensyfikacji komunikacji wewnętrznej pomiędzy dzielnicami dolnej i górnej strefy miejskie oraz komunikacji miedzy miastami w paśmie Aglomeracji Trójmiejskiej. W związku z ambitnymi planami przebudowy przestrzennej tkanki miejskiej w dolnym Sopocie następuje niekorzystne zaburzenia tożsamości krajobrazu miejskiego poprzez przesunięcie środka energetyzujące go przestrzenie publiczne z terenu styku lądu i wody (mola) - na place o charakterze typowo miejskim.

Slowa kluczowe: energia przestrzeni publicznej na styku lądu i wody, miasto nadmorskie, uzdrowisko nadmorskie - degradacja, molo jako przypadek przestrzeni komercyjnej.

\section{Wprowadzenie}

Nadbałtycki kurort Sopot jest odpowiednim podmiotem do analiz nowych tendencji w kreowaniu współczesnej przestrzeni miejskiej w kilku znaczących obszarach związanych z:

- architekturą mieszkaniową i architekturą użyteczności publicznej;

- budowy optymalnych relacji wzajemnych miasta i pasma krajobrazu przyplażowego na styku Parków Nadmorskich, plaż i wód Zatoki;

- komunikacji wewnętrznej pomiędzy obszarami dzielnic mieszkalnych dolnej i górnej części miasta Sopotu.

Walory krajobrazowe Sopotu, najbardziej zielonego miasta w Polsce, kurortu znanego od początku XIX wieku, stanowią o wielkiej sile przyciągającej nad morze osoby spragnione odpoczynku od wszechobecnego pośpiechu i zgiełku. Nowe wyzwania stojące przed projektantami i realizatorami współczesnej wizji kurortu - reklamowanego jako „Kurort Pełen Życia" - obejmują zharmonizowanie nowych punktów energetycznych w mieście $\mathrm{z}$ równoczesną pielęgnacją legendy eleganckiego uzdrowiska.

\section{Synergia w Sopocie - kurorcie nadmorskim}

Właściwie rozumiane poszukiwanie „Synergii w architekturze” kurortu musi być poprzedzone ustaleniem podstawowych ograniczeń w budowaniu dobrej energii miasta jako całości. Podstawową utrudnieniem jest utrwalone od 1824 roku [Romanow, 1998, s.108] rozwarstwienie osady na dwie zupełnie różne pod względem tektonicznym części: Górny Sopot i Dolny Sopot ${ }^{1}$. Obecnie mamy do czynienia z układem typu „sandwich ”, bowiem

${ }^{1}$ wg Romanowa od 2 maja 1824 zatwierdzano nazwy sopockich ulic i numery domostw osobno dla 
miasto Sopot położone jest na trzech poziomach - dolnym nadmorskim, środkowym przyporządkowanym linii kolejowej i drodze szybkiego ruchu z Gdańska do Gdyni oraz górnym (wzgórza morenowe).Trzy pasma miejskie równoległe do linii brzegu morskiego wraz z poprzecznymi uliczkami i ulicami tworzą „strukturę grzebieniowatą”, przy czym drogi poprzeczne rozdzielają pasma poziome po to aby można było dojść (dojechać) w kilku miejscach na plażę. Niestety stanowią o poszatkowaniu terenu miejskiego, nie harmonizują całości struktury pod względem energetycznym.

Część Górnego Sopotu jest unikatowo zachowanym „skansenem” kameralnej dzielnicy parkowo- leśnej, obejmującej zabytkową zabudowę kilku kolejnych wzgórz i dolin wraz z lasami, ogrodami i zbiornikami wodnymi. Tu zachował się Duch Haffnerowskiego Badu z początku XX wieku! Dzielnica wyposażona w tereny sportowe, miejsca spacerowe, szlaki turystyczne, Operę Leśną, tereny narciarskie, punkty widokowe, parki, mieszany zabytkowy Las, oferuje cały rok możliwości rekreacji mieszkańcom i turystom oraz wczasowiczom. Zrewitalizowana Opera Leśna, obiekty nowego gmachu Filharmonii Kameralnej w lesie, tereny ścieżek i tras narciarskich, zabytkowy Stadion Leśny oraz jezioro Morskie Oko, budują piękno i energię Sopotu Górnego.

Czyste powietrze, odizolowanie dzielnicy (dzięki zabytkowej bujnej zieleni parkowej) od hałasu głównej arterii komunikacyjnej, pozwala tej mimo braku bezpośredniego kontaktu z plażą i molem, przypisać miano Uzdrowiska-Kurortu. W Górnym Sopocie mieszka się „jak dawniej” - mieszkańcy identyfikują się Sopotem - miastem dobrym do życia. Dzielnica „, profesorska” charakteryzuje się tym, że żyje się tutaj spokojnie i długo. To w Górnym Sopocie podjęto trud realizacji kompleksu nowego Centrum Opieki Geriatrycznej dla Trójmiasta, nowoczesnego zespołu szpitalno-rehabilitacyjnego dla osób długowiecznych, a wewnątrz dzielnicy mieszkaniowej Mickiewicza z lat 70-tych ubiegłego wieku samorządowcy zrealizowali cztery piękne wielopokoleniowe place Kultury Fizycznej dla aktywnych Sopocian na terenach Parku Osiedlowego. Wytworzyła się nowa społeczość mieszkańców utożsamiających się ze swoim miejscem zamieszkania -odpowiedzialnych, aktywnych, nie ma poczucia anonimowości.

Architektura eleganckich willi mieszkalnych sprzed 80lat, stanowi o uroku Sopotu Górnego - jest to miejsce ,z klimatem”. Im bliżej jednak do drogi szybkiego ruchu na osi północ-południe - w miejscu historycznego jedynego traktu z Gdańska do Wejherowa tym jest głośniej i, niestety, bezpodmiotowo.

Miasto obrasta w tkankę bardzo intensywnej zabudowy, rozmaitej urody kamienicami, domkami i domami wielorodzinnymi o różnej kubaturze. Po obu stronach traktu komunikacyjnego, oddzielone wąskimi chodnikami od jezdni trwają w systemie XIX-wiecznych pierzei bardzo różne kamieniczki, obok piętrowych, 4-piętrowe, parterowe. Niejednorodność stylistyczną dopełniają zaniedbane oficyny od strony torów kolejowych, co stwarza dyskomfort funkcjonalny dla mieszkańców, najemcy obiektów przy trakcie skazani są na smog, powietrze pełne spalin, hałas całodobowy, prymitywną komunikację wewnętrzną, szpetotę i tandetę zabudowy podwórkowej, sąsiedztwo pustostanów po dawnych obiektach sklepowych. Mieszkańcy poddawani są złej energii miejsca, zresztą, co ciekawe, mieszkańcy są jakby niewidoczni. Partery kamienic z opuszczonymi pustymi, brudnymi szybami okien wystawowych degradują status sopockiego odcinka Alei Niepodległości. Równolegle przebiegająca linia kolejowa $\mathrm{z}$ nowo powstałym w miejscu dawnego budynku dworcowego, przeskalowanym zespołem nazwanym na wyrost nowym Centrum Sopotu, dzieli Sopot na różne mikroświaty osadzone na trzech tarasach, opadających w stronę plaży.

Sopotu dolnego i górnego. Było to ciekawym zjawiskiem świadczącym o braku istnienia więzi pomiędzy dzielnicami osady (przyp. autorki) 


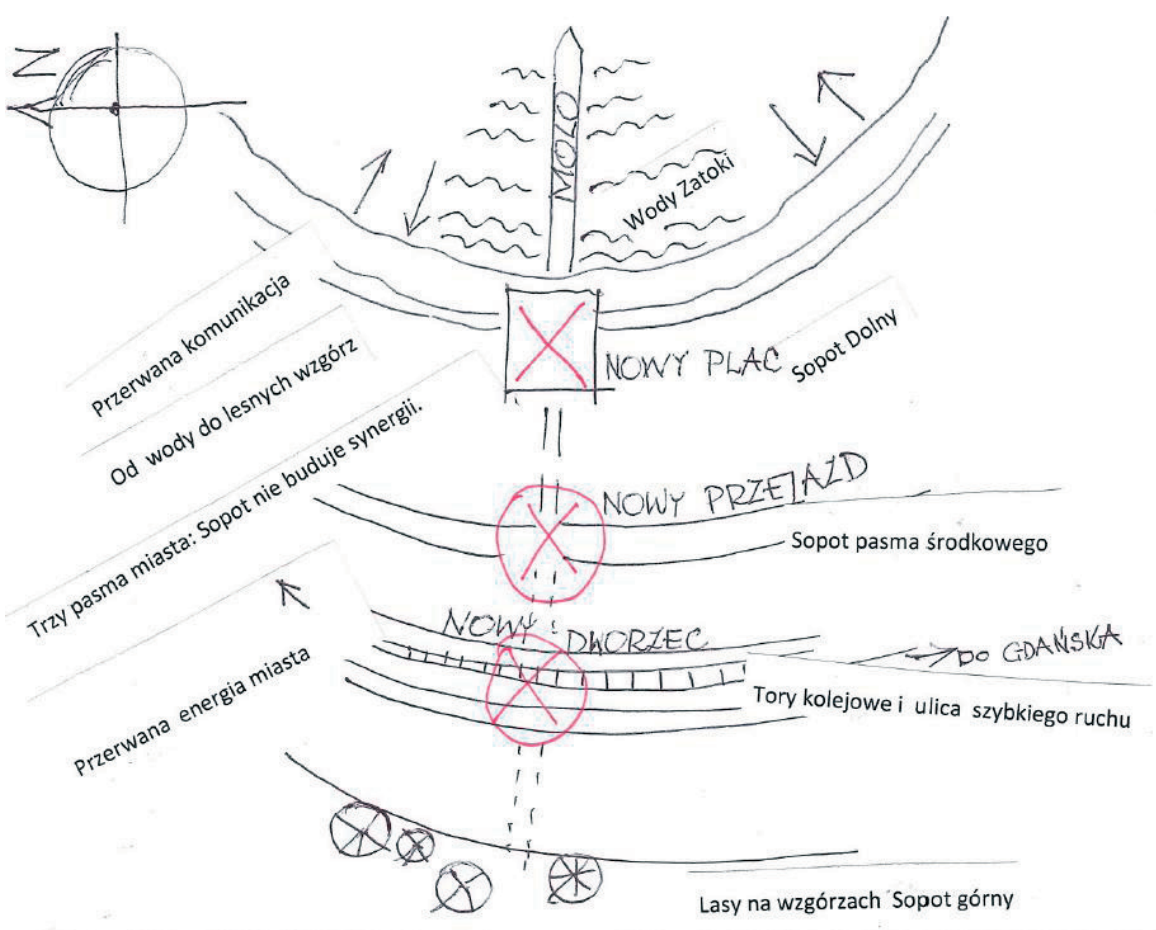

Kurort nadmorski Sopot - brak synërgii

Rys. 1. Mikroświaty Sopotu - stan obecny: zaburzenia przepływu energii, rys. własny

\section{Przyczyny powstawania zjawiska przerywania przepływu energii uzd rowiska Sopot przez - relikty XIX-wiecznego organizmu miejskiego pasma środkowego.}

Środkowe pasmo miasta Sopotu jest elementem wstęgowej obudowy trasy tranzytowej kołowej oraz linii kolejowej. Elementy komunikacyjne nadają rytm przestrzeniom mieszkania i zdecydowanie przypominają typowe miasto z początku ubiegłego wieku. Całe pasmo zabudowy jest koncepcyjnie podporządkowane ukształtowaniu historycznej linii trasy tranzytowej kolejowo-drogowej, i nie kojarzy się przybyszom z głębi lądu z kurortem, stworzonym w celu odnawiania zasobów ciała i ducha na łonie przyrody nadmorskiej. Tereny tzw. zespołu Sopotu środkowego są położone kilkadziesiąt metrów wyżej niż tereny zagospodarowane jako gospodarstwo przyplażowe. W chwili obecnej programowo nie kontaktują się, nie spajają i nie stanowią elementu jednoczącego energetycznie zacisze Górnego miasta ze strefą publicznej przestrzeni deptaka i placów przed molem, nie wspominając już o Parkach Nadmorskich -Południowym i Północnym. Należy z żalem podkreślić, że znajdująca się w Parku Haffnera przestrzeń zielona zawiera opuszczony obiekt Willi Herbstów, z terenami pozostałymi po słynnych ogrodach, szklarniach, ogrodnictwie itd., pielęgnowanymi przez rodzinę słynnego mecenasa i sponsora sopockich obiektów użyteczności publicznej [Sperski, 1998, s.35]. Istniejące przy ulicy Szkolnej także i inne monumentalne wille $\mathrm{z}$ ogrodami, powoli tracą blask ( np. stylowa willa Piotrowskiego czeka na sprzedaż). 


\section{Próba uzasadnienia braku synergii pomiędzy trzema pasmami zabudowy}

Budowa miasta-kurortu nadmorskiego obróconego „twarzą do morza” ma specyfikę pasmową. Równoległość kolejnych pasm zabudowy tworzy układ wstęgowy.

Najbardziej interesująca krajobrazowo jest wstęga obszaru zagospodarowanego w bezpośredniej bliskości wody. Najbardziej klimatyczne uliczki z zabudową willową i zabytkowymi kamieniczkami znajdują się w paśmie zabudowy przy plaży, oddzielone wydmami od terenu rekreacji plażowej. Dolny Sopot zaopatrzony jest w pensjonaty, hotele, miejsca rekreacji sportowej(marina, korty tenisowe) i tereny spacerowe w Parkach po południowej i północnej stronie mola. Molo stanowi unikatowy obiekt rekreacyjny o niespotykanej sile oddziaływania na wszystkich przybywających do kurortu turystów, a także ulubione przez cały rok miejsce spacerów. Zabytkowy Zakład Balneologiczny, obecnie zrewitalizowany, działa od roku 1956 jako Centrum Rehabilitacji i Kultury Sportowej. Niemniej jednak powstała wąska szczelina oddzielająca tereny Placu miejskiego zwanego obecnie Placem Przyjaciół Sopotu od zabytkowego Placu zwanego teraz Skwerem Kuracyjnym, w postaci podziemnej nitki komunikacji kołowej w ciągu ulicy Grunwaldzkiej na odcinku od wejścia na Molo aż do nowego zespołu hotelowego, obok znanego wszystkim hotelu GRAND. Dzięki temu zabiegowi planistycznemu, zniknął aspekt rekreacyjny niespiesznego spacerowania, na osi słynnego deptaka sopockiego (dawnej ulicy Morskiej, obecnie ul. Bohaterów Monte Cassino) w kierunku od placu - rynku przed kościołem św. Jerzego domola i z powrotem.

Do czasu zbudowania tunelu „towarzysko bywać w Sopocie” znaczyło zaistnieć fizycznie na owej historycznej promenadzie, pokazać się z najlepszej strony, koniecznie w gronie znajomych. Obecnie faktem stała się nowa sytuacja przestrzenna - istnienia dwóch placów. Pierwszy plac - na zakończeniu deptaka jest obudowany zespołem Domu Zdrojowego i hotelu oraz galerii, kin i restauracji w skali nawiązującej do stanu sprzed 1945 roku. Plac tętni życiem tylko w lecie i w czasie organizowanych imprez masowych. Masowy Odbiorca, tłum jest w tłoczony w, z góry narzuconą, narrację, wypełnia przestrzenie Placu Przyjaciół Sopotu w konkretnym czasie, a po imprezie rozpierzcha się, a nierozpoznawalny anonimowy odbiorca nie przenika już na molo(wejście na molo jest płatne w sezonie). Placyk prowadzący do kas na molo, stanowi rozszerzenie miejsca spacerowego i prowadzi do stylowego wejścia do siedziby zabytkowego zakładu rehabilitacyjnego [Sperski, 1998, s.46], nie zaś Plac do przebywania rekreacyjnego w kurorcie...

Kolejne drugie, pasmo zabudowy miejskiej obejmująca zabudowę hotelowo- mieszkaniową, jest niewątpliwie zabytkowa, lecz raczej niejednorodne w skali a także - estetycznie. Stanowi strukturę budowli nienawiązujących do charakteru dzielnicy pensjonatowej w pobliżu plaż i nie współpracuje z przestrzeniami nadwodnymi. Posiada charakter raczej usługowy-gromadzi w sobie mieszkania, sklepy, banki, restauracje.

Trzecia pasmo zabytkowego zespołu urbanistyczno-architektonicznego - nazywane Górnym Sopotem - jest najbardziej jednorodnym zespołem ekskluzywnej zabudowy z początków XX wieku i jest, co już powiedziano na wstępie, oddzielona dosłownie i w przenośni od całej reszty miasta. Jest zdecydowanie inne estetycznie niż część przyplażowa, w klimacie, inna w architekturze, inaczej skomunikowana wewnętrznie. Jest najstaranniej zrealizowanym przedsięwzięciem mieszkaniowym na terenie Sopotu, a także i najmniej zeszpeconym. Najważniejsze zaś jest to, że posiada własny wspaniały klimat i energię, mimo że nie czerpie energii z dynamiki morza. 

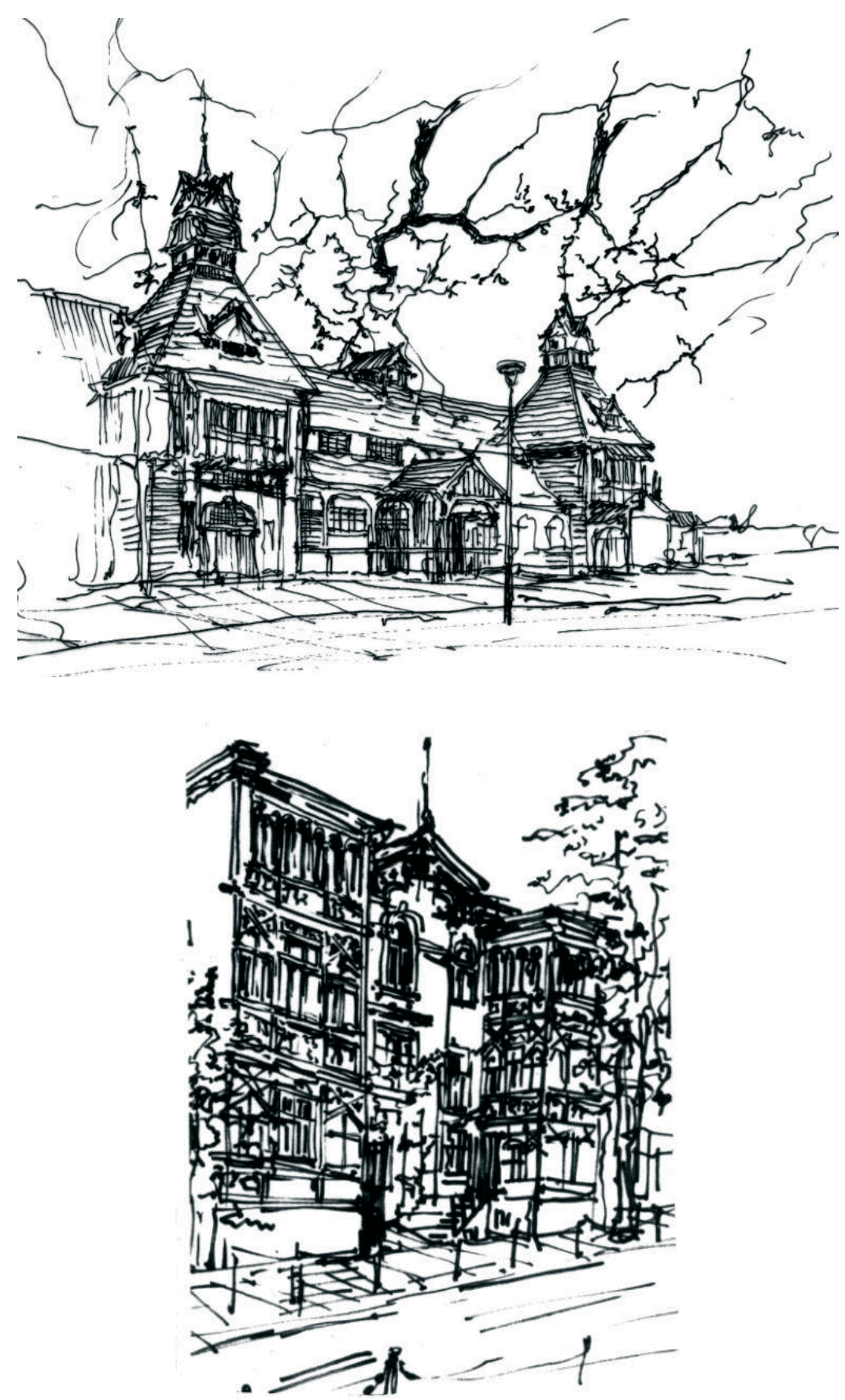

Rys. 2. Stylizowana architektura z I połowy XX wieku - Łazienki Południowe (arch. Puchmuller), kamienica czynszowa z werandami na ul. Grunwaldzkiej 

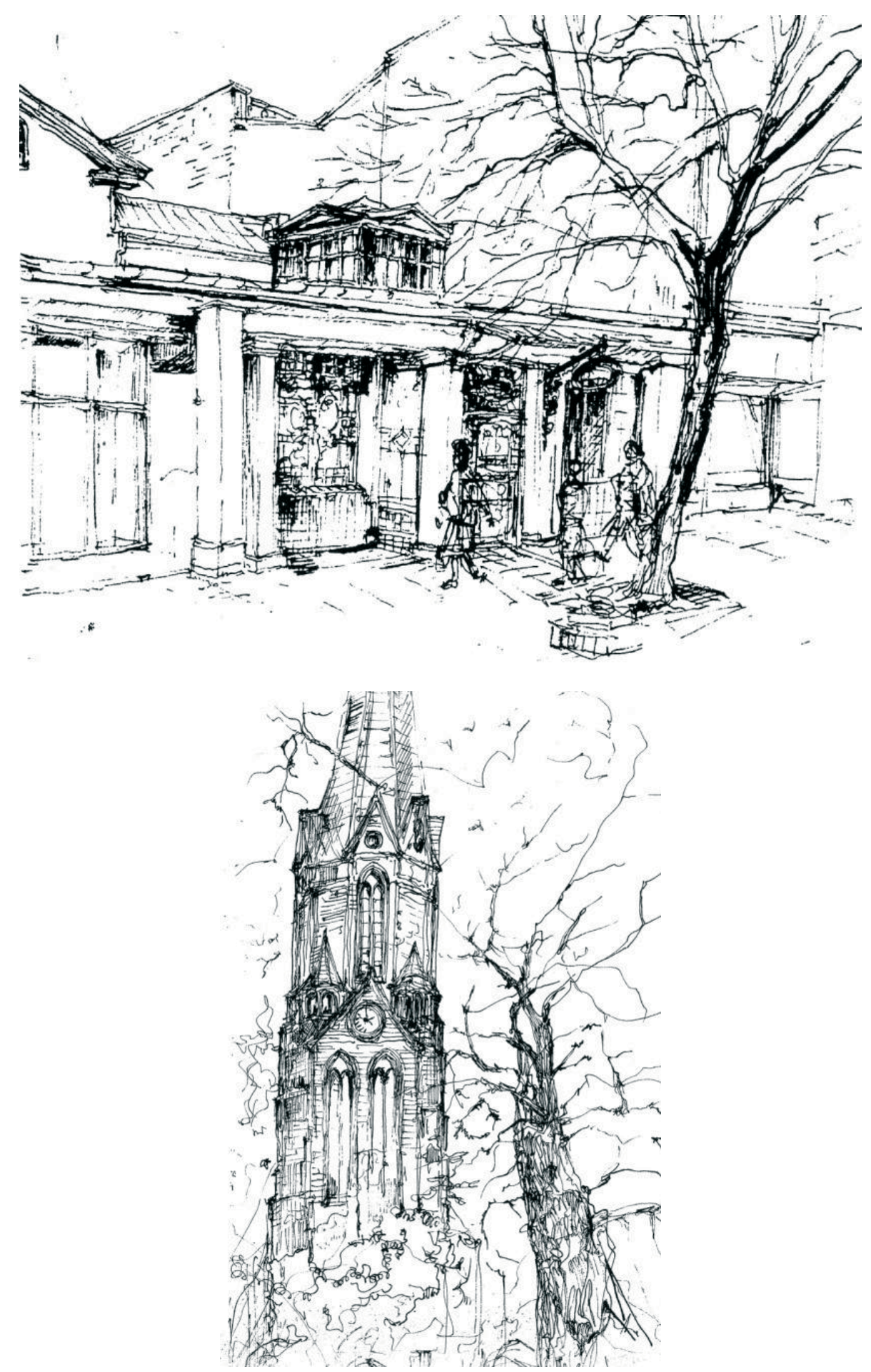

Rys. 3. Relikt dawnego kurortu, powojenny klub EMPIK-u, zburzony w 2003 roku. Wieża kościoła św. Jerzego na placu w centrum miasta 


\section{Połączenia poprzeczne pomiędzy pasmami miasta nadmorskiego - Sopotu}

Sytuacja skomunikowania zurbanizowanej środkowej części Sopotu poprzez zachowany, historyczny układ systemu uliczek i ulic poprzecznych do osi głównej dawnego traktu z tkanką zurbanizowana w bezpośredniej bliskości plaży, nie tworzy nowej energetycznej synergii. W chwili obecnej nie odczytano na kontynuowanie przedłużania atrakcyjnych ciągów pieszo-jezdnych z zalesionych wzgórz i parków miejskich poprzez miasto w kierunku „z góry na dół”, do Parku i plaż. Nie ma prostego połączenia poprzecznego mola z Operą Leśną, nie ma historycznego sopockiego traktu konnego do Królewskiego Wzgórza. Wśród lasu.

Trzy zabytkowe osie połączeń poprzecznych są obecnie nieczytelne, brak nowej interesującej narracji w tworzeniu węzłów współcześnie interesującego spaceru od morza do leśnych wzgórz. Widoczny brak pomysłu na zaaranżowanie kameralnych miejsc publicznych w miejscach przecięcia poziomej ulicy głównej z poprzecznicami, skutkuje w chwili obecnej nie istnieniem zjawiska synergii architektonicznej w kurorcie.

\section{Rozważania na temat synergii wewnątrz obszaru zabudowy tzw. Centrum Sopotu}

Po pierwsze deptak, dawna ul. Morska, staje się miejscem mało gościnnym, nie ma kawiarenek, na trotuarach, są restauracje, nie pachnie kawą ... Po drugie nieczytelna jest część ulicy prowadzącej do Opery w lesie znanej jako kontynuacji spacerowej linii pieszej i dorożek konnych dla kuracjuszy sopockich w przeszłości... Zlikwidowano hale targową i zbudowano parking płatny i dom handlowy, odnowiono Gmach zabytkowego Sądu $\mathrm{z}$ aresztem, obiekty bankowe, domykają pierzeje dawnego Rynku. Wspaniała, nowoczesna Opera Leśna jest odizolowana od całej struktury wypoczynkowej miasta. Podobnie zespół stadionowy, stadion w lesie, ścieżki wokół jeziora Morskiego Oka czekają na nowe odczytania. Podobnie dzieje się z drogami tras turystycznych od i do Osiedla Mickiewicza i okolic.

Dzielnice willowe Górnego Sopotu nie bez powodu wybierali jako miejsce stałego zamieszkania wszyscy znakomici architekci sopoccy. Są tu bajeczne wille architektów sopockich Bilefelda, Puchmillera, przemysłowców, profesorów, elity inteligencji przedwojennej. Zachowały się tu także zabytkowe założenia ogrodowe z okresu największej świetności Badu Zoppot (Sopoty)

Z kolei, współczesna ulica równoległa do deptaka i komunikująca Nowy Zespół Dworcowy z plażami oraz Łazienkami Południowymi została zawężona przez zastosowanie z części chodnika ścieżki rowerowej w kierunku morza, i przez to stała się nieprzyjazna dla pieszych.

W chwili obecnej-trudno jest odczytywać istnienie synergii w zespole miejskim Sopotu, kameralnym z natury, w którym sezonowe następuje zmiana ilościowa użytkowników terenu nadmorskiego i obiektów usługowych w przestrzeni śródmiejskiej.

Współistniejące, z założenia zmienne sezonowe dynamiki sposobu użytkowania przestrzeni publicznej nadmorskiej i wewnątrz miejskiej stanowią o trudności poszukiwania równowagi energetycznej, a co dopiero SYNERGII.

Reasumując: można zobrazować (określić) zmienność dynamiki użytkowania przestrzeni publicznej w mieście nadmorskim- uporządkowanych wg podstawowych czterech pór roku (patrz tabela 1). 
Tabela 1. Zmienność dynamiki użytkowania przestrzeni publicznej w mieście nadmorskim wg podstawowych czterech pór roku. Oprac. K. Pokrzywnicka 2015

\begin{tabular}{|c|c|c|c|c|}
\hline Pora roku & Lato & Jesień & Zima & $\begin{array}{l}\text { Wiosna } \\
\text { (od } 1 \text { maja - początek } \\
\text { sezonu letniego) }\end{array}$ \\
\hline $\begin{array}{l}\text { aktywności } \\
\text { działania } \\
\text { energetyzujące } \\
\text { przestrzeń } \\
\text { publiczną } \\
\text { miejską i } \\
\text { nadmorską }\end{array}$ & $\begin{array}{l}\text { imprezy sportowe } \\
\text { na kortach } \\
\text { tenisowych } \\
\text { zawody } \\
\text { hippiczne - } \\
\text { wyścigi } \\
\text { międzynarodowe } \\
\text { spotkania w Ergo } \\
\text { Arenie } \\
\text { jachting } \\
\text { festiwale } \\
\text { kulturalne, } \\
\text { filmowe } \\
\text { przedstawienia } \\
\text { operowe w } \\
\text { plenerze }\end{array}$ & $\begin{array}{l}\text { festiwale } \\
\text { teatralne i } \\
\text { filmowe } \\
\text { imprezy } \\
\text { sportowe, tenis } \\
\text { mecze piłkarskie } \\
\text { wyścigi konne,, } \\
\text { plaża i Park } \\
\text { Nadmorski - } \\
\text { aktywności } \\
\text { ekstremalne - np. } \\
\text { paralotnie } \\
\text { kappiele morskie } \\
\text { dla amatorów, } \\
\text { zabiegi } \\
\text { rehabilitacyjne, w } \\
\text { obiektach } \\
\text { specjalistycznych } \\
\text {, kąpiele w } \\
\text { ogrzewanej } \\
\text { wodzie morskiej, } \\
\text { biegi uliczne, } \\
\text { maratony } \\
\text { rejsy } \\
\text { wycieczkowe od } \\
\text { maja do końca } \\
\text { sezonu }\end{array}$ & $\begin{array}{l}\text { imprezy } \\
\text { kulturalne } \\
\text { (festiwale } \\
\text { teatralne, } \\
\text { filmowe, } \\
\text { muzyczne,) } \\
\text { koncerty w Sali } \\
\text { Filharmonii } \\
\text { Kameralnej, } \\
\text { sporty } \\
\text { narciarskie, skoki } \\
\text {,biegi w terenach } \\
\text { i na trasach } \\
\text { leśnych } \\
\text { imprezy sportowe } \\
\text { dla łyżwiarzy, } \\
\text { lodowisko w } \\
\text { Centrum } \\
\text { Haffnera } \\
\text { kuligi } \\
\text { bale } \\
\text { karnawałowe }\end{array}$ & $\begin{array}{l}\text { spacery sportowe nad } \\
\text { morzem, } \\
\text { spacery rekreacyjne, } \\
\text { rejsy rowerowe po } \\
\text { plaży i wzdłuż tras dla } \\
\text { rowerzystów, imprezy } \\
\text { sportowe w zamkniętej } \\
\text { hali Stulecia, } \\
\text { wystawy zwierząt } \\
\text { rasowych -psów } \\
\text { kotów, ptaków itp. itd. }\end{array}$ \\
\hline
\end{tabular}

Istotnym zjawiskiem jest to, że energia $\mathrm{w}$ miejscach tych jak widać z podanego poniżej zestawienia, trwa nieprzerwanie przez cały rok kalendarzowy. Niemniej jednak rozkłada się nierównomiernie. Poniżej przedstawione zostały wyszczególnione najbardziej energetyczne miejsca kurortu Sopotu(patrz tabela nr 2).

Tabela 2. Miejsca energetyczne w kurorcie wg pór roku. Oprac. K. Pokrzywnicka 2015

\begin{tabular}{ll}
\hline Pora roku & Miejsce i obszary miejskie z dobrą energią \\
\hline Wiosna & parki nadmorskie i miejskie skwerki, ścieżki rowerowe, siłownie na powietrzu \\
\hline Lato & parki nadmorskie, plaże, korty tenisowe, boiska sportowe \\
\hline Jesień & parki nadmorskie, brzeg morski, boiska i korty tenisowe \\
\hline Zima & $\begin{array}{l}\text { trasy biegowe narciarskie i trasy saneczkowe, kryte sale sportowe, pływalnie, zabiegi } \\
\text { rehabilitacyjne }\end{array}$ \\
\hline
\end{tabular}

Rekreacyjne pasmo nadmorskie miasta Sopotu - inaczej-przestrzeń bezpośredniego styku lądu i wody rozumiana jako publiczna przestrzeń rekreacyjna otwarta całorocznie dla mieszkańców i wczasowiczów. Atutem tej niezwykłej, unikatowej przestrzeni publicznej obdarzonej walorami krajobrazu nadmorskiego, jest przepływ energii od morza do miasta, autentyczna tożsamość krajobrazowa, niestety bezbronna wobec antropopresji przyrodniczej i bezwzględnej działalności inwestorskiej wzdłuż całej plaży. Postępująca urbanizacja, zabudowa terenów nadmorskich w Sopocie pozostawia miasto bez dopływu energii od 
morza. Widok na morze w czasie spaceru Parkiem Nadmorskim staje się coraz mniej oczywisty. Morze oddziela od terenów zielonych zaprojektowanych przede wszystkim z myślą o klasycznej, kompleksowej rekreacji powietrzno-wodnej przez projektantów terenów nadmorskich, już w tej chwili szczelna ściana rozmaitych wytworów architektury zdumiewająco niejednorodnej, szpetnej, zawłaszczającej tereny wydm i plaży. Urbanizacja pasma w bliskości całej sopockiej plaży jest najbardziej niekorzystnym zjawiskiem ostatnich lat w życiu miasta, zjawiskiem deprecjonującym klimat i aurę Sopotu. Deenergetyzującym działaniem w najpiękniejszym odcinku słynnych plaż sopockich. Specyfiki krajobrazu nadmorskiego nie uda się odtworzyć z dnia na dzień. Kurort traci energię

Dla nadmorskiego miasta zetkniecie się lądu i wody są przestrzeniami, gdzie estetyka krajobrazu powinna narzucać swoją indywidualność znajdującej się w jej przestrzeni architekturze. Aktualnie powstająca W Sopocie architektura zdaje się ignorować kontekst, w którym przyjdzie jej zaistnieć. Można by w związku z tym wyodrębnić istnienie we współczesnej rzeczywistości architektonicznej dwóch niezależnych zjawisk: z jednej strony nieodczytywalny jest kontekst współczesnego miasta - zarówno morfologiczny, socjologiczny, jaki i kulturowy, z drugiej istnieje zjawisko realizowania architektury niezależnie od tkanki miasta Tak więc sytuacja stwarza pole do „nadużyć przestrzennych”, rozumianych jako oznaki lekceważenia wartości kulturowych, krajobrazowych i uwarunkowań klimatyczno-przyrodniczych.

W chwili obecnej mamy do czynienia z nienotowaną od czasu powstania Uzdrowiska, dynamikę procesów przebudowy, i rozbudowy nowego kompleksu budynków użyteczności publicznej Sopotu wraz z przebudową struktury komunikacyjnej w zabytkowej tkance śródmieścia, polegającą na realizacji tunelu podziemnego dla pieszych, który to tunel ma usprawnić ,przelewanie” masy turystów pieszych z deptaka na molo. Tunel umożliwi ruch ciągły pojazdów i bezkolizyjne przejście pieszych z ul. Monte Cassino w kierunku mola i plaży. Pod ziemią samochody mają w przyszłości pokonywać $70 \mathrm{~m}(200 \mathrm{~m}$ z pochylniami). Nowe centrum diametralnie zmieniło wygląd i charakter tej części miasta. Powstanie nowoczesne nawiązujące do nadmorskiego centrum Sopot, który przed wojną był przede wszystkim kurortem dla Polski i Europy. Rysuje się nowy wyraz sopockie przestrzeni publicznej - przyplażowej, przede wszystkim serca całego układu, czyli placu z Nowym Centrum Haffnera, placem przed molo i molo sopockim.

\section{Synergia nadmorskiej przestrzeni publicznej Sopotu. Cechy nadmorskiej przestrzeni publicznej Sopotu}

- We współczesnym mieście, niezależnie od tego, czy jest to miasto nadmorskie czy śródlądowe, przestrzeń publiczna jest Znaczącą Przestrzenią, która powinna być troskliwie pielęgnowanym Miejscem Wspólnym,

- przestrzeń publiczna miasta nadmorskiego znamionuje autonomia wobec reszty miasta, a specyficzne cechy krajobrazu nadwodnego należy odczytać, odnaleźć i uszanować; w celu zminimalizowania niekorzystnych zjawisk antropopresji w struktury przyrodnicze,

- fenomen Przestrzeni Publicznej w krajobrazie nadmorskim powinien być uznany przez administratorów miasta jako Dobro Wspólne miasta nadmorskiego.

Jako podsumowanie zawartych $\mathrm{w}$ tabeli informacji na temat synergii pasma lądu i wody-wypunktowano niezbędne działania mające na celu zachowanie i utrzymanie jej walorów nadmorskich:

- podniesienie efektywności przestrzeni - różne formy rekreacji i rehabilitacji na świeżym powietrzu na wydzielonej części plaży; 
- edukacja przyrodnicza społeczeństwa - całoroczna dbałość wolontariuszy o tereny wydmowe;

- edukacja społeczna w celu zapobiegania wandalizmowi i zaśmiecaniu terenów zielonych;

- zorganizowany, 24-godzinny monitoring;

- pomiędzy aleją spacerową w Parku Nadmorskim a pasmem wydm i plażą;

- zmiany skali wysokości zabudowy pomiędzy aleją spacerową w Parku Nadmorskim a pasmem wydm i plażą.

Tabela 3. „Porównanie przestrzeni publicznych w mieście śródlądowym i w mieście nadmorskim”*)

\begin{tabular}{|c|c|c|}
\hline & $\begin{array}{l}\text { Przestrzeń publiczna } \\
\underline{\text { miasto śródlądowe }}\end{array}$ & $\begin{array}{l}\text { Przestrzeń publiczna } \\
\text { miasto nadmorskie }\end{array}$ \\
\hline \multicolumn{3}{|l|}{$\begin{array}{l}\text { Cechy przestrzeni } \\
\text { Wybrana cecha } \\
\text { charakterystyczna }\end{array}$} \\
\hline Dostępność przestrzeni & latwo dostępna & dostępna w zależności od pogody \\
\hline $\begin{array}{l}\text { Wyjątkowość - } \\
\text { unikatowość }\end{array}$ & $\begin{array}{l}\text { zależna od struktury zabudowy i } \\
\text { krajobrazu przyrody: różna }\end{array}$ & $\begin{array}{l}\text { niepowtarzalna, dynamicznie } \\
\text { zmienna, organicznie związana z } \\
\text { krajobrazem nadmorskim }\end{array}$ \\
\hline Geneza powstawania & $\begin{array}{l}\text { zależny od wieku miasta i ewolucji } \\
\text { potrzeb środowiska miejskiego - } \\
\text { późniejszy niż miasto; równoczesny z } \\
\text { narodzinami miasta, wcześniejszy, } \\
\text { np. centrum kultowe }\end{array}$ & $\begin{array}{l}\text { ponadczasowość - niezależność od } \\
\text { datowania historii osiedleńczej }\end{array}$ \\
\hline Trwałość & $\begin{array}{l}\text { zależna od troskliwości } \\
\text { użytkowników i gospodarności } \\
\text { decydentów }\end{array}$ & $\begin{array}{l}\text { niezależna od polityki gospodarzy; } \\
\text { degraduje się i odradza według praw } \\
\text { przyrody }\end{array}$ \\
\hline $\begin{array}{l}\text { Stopień zainwestowania } \\
\text { i infrastruktury }\end{array}$ & $\begin{array}{l}\text { zależny od planów rozwoju i potrzeb } \\
\text { eksploatacyjnych konkretnego miasta }\end{array}$ & $\begin{array}{l}\text { istnieje jako przestrzeń } \\
\text { przystosowana jedynie częściowo do } \\
\text { użytkowania przez mieszkańców, ale } \\
\text { też narażona na dewastację i } \\
\text { degradację ogólno przyrodniczą }\end{array}$ \\
\hline $\begin{array}{l}\text { Interpretacja stosunku } \\
\text { własności i wspólnoty }\end{array}$ & $\begin{array}{l}\text { przestrzeń z założenia wspólna dla } \\
\text { wszystkich stałych i niestałych } \\
\text { mieszkańców miasta }\end{array}$ & $\begin{array}{l}\text { przestrzeń wspólna pojemna i } \\
\text { elastyczna o dynamicznie } \\
\text { zmniejszonej pojemności (sezonowej) }\end{array}$ \\
\hline $\begin{array}{l}\text { Autonomia wobec } \\
\text { organizmu miejskiego }\end{array}$ & $\begin{array}{l}\text { przestrzeń ściśle związana i } \\
\text { podporządkowana życiu miasta }\end{array}$ & $\begin{array}{l}\text { przestrzeń autonomiczna wobec } \\
\text { miasta }\end{array}$ \\
\hline $\begin{array}{l}\text { Wykorzystanie - } \\
\text { zagospodarowanie }\end{array}$ & $\begin{array}{l}\text { miejsce kultu; } \\
\text { miejsce odpoczynku; } \\
\text { miejsce komercyjne; } \\
\text { miejsce aktywności kulturalnej; } \\
\text { miejsce aktywności politycznej; } \\
\text { miejsce imprez; sportowych } \\
\text { masowych; } \\
\text { wizytówka turystyczna miasta; }\end{array}$ & $\begin{array}{l}\text { miejsce odpoczynku biernego; } \\
\text { miejsce komercyjnej działalności; } \\
\text { miejsce dla imprez sezonowych } \\
\text { sportowych i teatralnych; } \\
\text { wizytówka turystyczna miasta; } \\
\text { miejsce niekonwencjonalnej } \\
\text { działalności młodych; } \\
\text { (szacunek dla praw przyrody); } \\
\text { miejsce magiczne uzdrawiające; }\end{array}$ \\
\hline Walor edukacyjny & $\begin{array}{l}\text { odczytywalny historycznie } \\
\text { kontynuowane } \\
\text { zagospodarowanie }\end{array}$ & $\begin{array}{l}\text { Odczytywalny przekaz potrzeby } \\
\text { szacunku dla tożsamości } \\
\text { krajobrazowej styku morza i } \\
\text { środowiska zagospodarowanego } \\
\text { przez użytkownika miasta, } \\
\text { środowiska zurbanizowanego }\end{array}$ \\
\hline Walor terapeutyczny & nieistotny & $\begin{array}{l}\text { wieloraki, związany z kultura } \\
\text { ochrony zdrowia jednostki }\end{array}$ \\
\hline
\end{tabular}

*)Tabela powyżej - autor: Krystyna Pokrzywnicka 


\title{
Literatura
}

1. Andrzejewski M. Dzieje Sopotu w latach 1920-1945. Dzieje Sopotu do roku 1945. (ed. Śliwiński B.), Oficyna Pomorska, Gdańsk 1998, s.171.

2. Romanow A. Sopot w latach 1818-1920. Dzieje Sopotu do roku 1945. (ed. Śliwiński B.), Oficyna Pomorska, Gdańsk 1998, s. 108.

3. Sperski M. Rozwój przestrzenny Sopotu. Dzieje Sopotu do roku 1945. (ed. Śliwiński B.), Oficyna Pomorska, Gdańsk 1998, s.35.

4. Stankiewicz J., Szermer B. Pobrzeże Gdańskie Krajobraz i architektura. (ed. Biegańska E.), Arkady, Warszawa 1961, s .33.

5. Juchnevic K., Pokrzywnicka K. Energia przestrzeni publicznej współczesnego miasta. Colloquium Wydziału Nauk Humanistycznych i Społecznych, Kwartalnik 2/2013, Gdynia 2013, str. $121-128$.

\section{Synergy in the seaside resort architecture - Sopot case study}

\section{Krystyna Pokrzywnicka}

Faculty of Architecture, Gdank University of Technology,

e-mail: krystyna_pokrzywnicka@op.pl

\begin{abstract}
Sopot - the most famous Baltic sea resort is excellent field for newest tendencies of researches, new tendencies for innovative thinking of spatial creation and synergy between commercial architecture, healthcare architecture and sport architecture in this sea-side town area. But number one is recognizing the relationship between seaside area and the city, as well as communication between three parts of the town, and energy cooperating between this areas of New Sopot.
\end{abstract}

Keywords: Architecture without energy, energy of the seaside public space, seaside town, energy disfunction of the seaside town, "Molo at Sopot" as the commercial space. 
